\begin{tabular}{|c|c|c|}
\hline Beitr. Ent. & Keltern & ISSN 0005 - 805X \\
\hline $54(2004) 2$ & S. 343-355 & 20.12 .2004 \\
\hline
\end{tabular}

\title{
Notes on fungus gnats from the East Mediterranean with description of two new species
}

\author{
(Diptera: Sciaroidea excl. Sciaridae)
}

With 10 figures

Olavi Kurina

Summary

Data on 24 fungus gnat species collected from the Greek mainland, Corfu Island, Greek islands adjacent to Asia Minor and Cyprus are presented. Two new species - Macrorrhyncha atticae sp. nov. and Megophthalmidia samosica sp. nov. - are described and detailed illustrations of genitalia for both species are given. The second known specimen is found for Ectrepesthoneura ledenikiensis BECHEv. Macrocera levantina CHANDLER is recorded from Europe for the first time.

\section{Zusammenfassung}

In vorliegender Arbeit werden Funde von 24 Pilzmückenarten von dem griechischen Festland, von Korfu, von den Kleinasien benachbarten griechischen Inseln und von Zypern gemeldet. Zwei neue Arten Macrorrhyncha atticae sp. nov. und Megophthalmidia samosica sp. nov. werden beschrieben und mit detaillierten Zeichnungen der Genitalien dargestellt. Das bisher einzige Exemplar von Ectrepesthoneura ledenikiensis BECHEV, wird durch ein weiteres Männchen ergänzt. Für Macrocera levantina CHANDLER liegt ein Erstfund in Europa vor.

\section{Keywords}

Diptera, Keroplatidae, Mycetophilidae, Macrorrhyncha, Megophthalmidia, new species, Greece, Cyprus.

\section{Introduction}

Fungus gnats are small to medium size, slender to moderately robust flies with highly characteristic morphology. They are distinguishable from other Nematocera by: strong thoracic and tibial bristles, wing venation, presence of ocelli, long coxae, strong apical spurs on tibiae (Søur et al. 2000). Fungus gnats are represented in Europe by five families (Bolitophilidae, Diadocidiidae, Ditomyiidae, Keroplatidae, Mycetophilidae) and form together with dark-winged fungus gnats (Sciaridae) the superfamily Sciaroidea. They are typical in forest ecosystems ( $\left.\varnothing_{\mathrm{KLAND}} 1994\right)$ and the majority of species are associated with fruit bodies or mycelium of different fungi at their larval stage (YaKovLEV 1994). 
The systematics of fungus gnats is based mainly on morphological characters, especially those in the structure of male genitalia. Some of the traditional genera are still heterogeneous pending taxonomic revisions. Moreover, the general classification of Sciaroidea is also an object of discussion at present.

Knowledge of the fungus gnat fauna in the Mediterranean region, in spite of some recent papers (e.g. Chandler 1994, Chandler \& Ribeiro 1995, Chandler \& Gatt 2000, Chandler \& Blasco-Zumeta 2001), is still scanty. According to Chandler \& BlascoZuMETA (2001) the Mediterranean fungus gnat fauna is smaller than that in northern Europe but includes a moderately large number of endemic species. The total Mediterranean fauna of this group exceeds 350 species (Chandler \& GATT 2000). BecheV (1997) summarized data about the Balkan Peninsula and referred to the distribution of 338 species. The synopsis on Israeli fungus gnats (CHANDLER 1994) contains data about 88 species, also referring to their distriburion in the whole Mediterranean region.

During my visit to the Zoological Museum in Amsterdam in 2001 I found a small amount of Sciaroid material collected from the Greek mainland and several East Mediterranean islands. Study of this material brought about the current paper.

\section{Material and methods}

The studied material includes 67 specimens (35 o $0^{*} 32$ 우 ㅇ) .25 of them were collected in the mainland of Greece, the others from its Islands: Corfu (1), Rhodes (11), Kos (2), Samos (5), Lesbos (11) and Cyprus (12). All material is dry pinned and taken by several collectors between autumn and late spring. There is a note on labels when a Malaise trap was used, otherwise collecting by sweeping is supposed.

When the observation of genitalia was unavoidable, they were treated by a standard method (macerated in hot $\mathrm{KOH}$, washed in acetic acid and distilled water and inserted into glycerine for study). The genitalia were preserved as glycerine preparations.

The material is deposited in the Zoölogisch Museum Amsterdam, Netherlands (ZMAN) if not shown otherwise. Two additional specially marked specimens are deposited in the Zoologische Staatssammlung in München, Germany (ZSM) and in Mr. A. SELrN's personal collection in Tallinn, Estonia (ASPC). In the species list original label data are cited.

\section{Results}

Nine species of Keroplatidae and 15 species of Mycetophilidae were found in the studied material, including two species new to science: Macrorrhyncha atticae sp. nov. and $M e-$ gophthalmidia samosica sp. nov. Additionally, 8 female specimens were determined to the genus level only. Eleven species were recorded from the Greek mainland while 1 from Corfu, 5 from Cyprus, 3 from Rhodes, 2 from Kos, 3 from Samos and 1 from Lesbos. In the following list some systematic and especially distributional features for the recorded species are discussed. 
The species

\section{Family Keroplatidae}

\section{Subfamily Macrocerinae}

\section{Macrocera fasciata MEIGEN, 1804}

Widespread in Europe including Crete and Cyprus (Krrvosheina \& Mamaev 1988, Chandler 1994). Found also from the Arabian Peninsula (Chandler 2000) and Motocco (Chandler \& Ribeiro 1995).

Material. Cuprus. 1 ? , Troodos mts., river $S$ of Mesopotamos Monastery, 900-1100m, 20 X 1992, P. Oosterbroek and F. M. Hartveld leg.; 3 ㅇ ㅇ, Troodos mts., 0-3 km W Galata, 650 m, 21-23 X 1992, P. Oosterbroek and F. M. Hartveld leg.

\section{Macrocera levantina CHANDLER, 1994}

According to Chandler's key (1994) the specimen runs to couplet ten because of the wing characteristics. Also the genitalia agree well with figures in the original description (Chandler 1994: Figs. 5-7). Described from Israel and probably distributed also in neighbouring areas (Chandler 1994), but since recorded only from Algeria (MarTINOVSKÝ 2001). First record for Europe, but it has recently been found in numbers in Portugal (Riberro \& Chandere in prep.) so is evidently widespread in the Mediterranean Region.

Material. Greece. $1 \delta^{*}$, Attiki, Dafni, $10 \mathrm{~km}$ W Athens, Malaise trap in phrygana, 14 I 1993, Th. Petanidou and V. Lengiou leg.

\section{Macrocera nigricoxa WINNERTZ, 1863}

The species was found to be a senior synonym of $M$. tusca LoEw, 1869 by BECHEV (1992). Widely distributed in western and central Europe (Krivosheina \& MaMaev 1988). According to CHANDleR (1994) there are several unpublished records from mainland Greece and eastern Mediterranean Islands.

Material. Greece. $1 o^{\star}$, Chalkidiki, Ayion Oros, M. Simon Petras, alt. 0-100 m, 5 VI 1984, J.W. Dienske leg.

\section{Macrocera phalerata MEIGEN, 1818}

The specimen runs according to CHANDLER's key (1994) to couplet seven and agrees with $M$. phalerata except in the absence of $\mathrm{R}_{4}$. Antennae are about 3 times as long as body, macrotrichia mainly on apical third of wing and only posthumeral spots present. Also genitalia are more similar (especially by internal margin of gonocoxite) to the figure by Hurson et al. (1980) of $M$. phalerata than the figure of the allied species Macrocera parcehirsuta BeCKer, 1907 by Chandler (1994). M. phalerata is widely distributed in Europe, including the Mediterranean (Chandler 1994, Chandler \& Gatt 2000).

Material. Greece. 1 ơ, Fokis, Delfi, 1 V 1990, O. R. Lengehr leg. 
Subfamily Keroplatinae

Antlemon balidayi (LoEW, 1871)

A Mediterranean species (Matile 1977, Chandler \& Gatt 2000). The Island Rhodes is one of the type localities from which the species was described (LoEw 1871).

Material. Greece. $1 \sigma^{\circ}$, Rhodos, Lindos, 1 IV 1970, A. C. and W. N. Ellis leg.; 10 , Rhodos, crossing road Rhodos-Kattavia and the Gaduras, 5 IV 1971, V. S. v. d. Goot leg.

\section{Keroplatus reaumurii DUfouR, 1839}

Holarctic species, recorded also from the Near-East (MATule 1986, Zarrzev 1994). According to literature not recorded from the Greek Islands previously.

Material. Greece. 1 o, Kerkyra, Dassia, 6 km Z.O. v. Korakiana, 16-30 V 1971, B. v. Aartsen leg.

\section{Macrorrbyncha geranias (LOEW, 1869)}

The species has previously been recorded only from Rhodes, the type locality of the species (MATnle 1975, Chandler 1994) but there are also unpublished findings from Milos (Chandler 1994).

Material. Greece. $5 \sigma^{\star} 1$ \%, Rhodos, Lindos, IIV, 10 IV and 18 IV 1970, A. C. and W. N. Ellis leg.

\section{Macrorrhyncha atticae sp. nov.}

(Figs. 1-3)

Type material. Holotype: male, Greece, Attiki, Dafni, $10 \mathrm{~km}$ W Athens, Malaise trap in phrygana, 20 I 1993, Th. Petanidou and V. Lengiou leg.

Description. Male. Length of wing $4.1 \mathrm{~mm}$.

Head blackish brown. Scape dark brown, while pedicel is a little lighter apically. Flagellar segments not preserved. Proboscis about as long as head. Proposcis basally brown, apically lighter, almost yellow. Palpi brown with yellowish apical segment.

Thorax entirely dark brown to blackish except yellowish anterior spiracle and prescutum. Scutum grey dusted, laterally slightly shining. Scutellum brown, slightly shining with six strong marginal bristles and with numerous setae. Anepisternum, proepisternum, laterotergite and mediotergite bare. Antepronotum and proepisternum both with one bristle; anterior spiracle with two black setae. Halteres entirely yellow, setose.

Legs yellow, with brownish tarsi. Fore coxa slightly brownish basally. Apical margin of fore trochanter brown anteriorly. Mid tibia with 5 anterior, 2 anteroventral, 5 posterior, 4 posteroventral and 3 ventral setae; hind tibia with 5 anterior, 4 anterodorsal, 6 dorsal, 5 posterodorsal, 9 posterior, and 3 posteroventral setae. Ratio of femur to tibia for fore, mid and hind legs: $0.83 ; 0.82 ; 0.74$. Ratio tibia to first tarsomere for fore, mid and hind legs: $1.38 ; 1.38 ; 1.57$. 
Wings hyaline. Veins $\mathrm{R}_{1}, \mathrm{R}_{4+5}, \mathrm{R}_{5}$ and distal part of $\mathrm{CuA}_{2}$ brown, other veins lighter. Veins $R_{1}, R_{4+5}, R_{5}, A_{1}$, apical $6 / 7$ of $M_{1}, M_{2}$ and $\mathrm{CuA}_{1}$, and apical half of $\mathrm{CuA}_{2}$ with setae. Sc ending in $\mathrm{C}$ before the base of Rs. $\mathrm{R}_{1}$ slightly thickened apically. $\mathrm{C}$ extending beyond apex of $R_{5}$ for length of $R_{4}$. Ratio R-M to $M-C u=0.8$. Ratio $R s$ to $M_{1+2}=1$.

Abdomen entirely blackish brown. Genitalia: Figs 1-3. Ninth tergite well emarginate, not constricted. Gonocoxite with very large dorsal lobe as no other species in the genus (Fig. 2).

Female. Unknown.

Biology. Unknown. Adults can presumably be found at umbellifer flowers.

Etymology. From the type locality in department of Attica, Greece: genitive form.

Discussion. The species runs according to MATILE's (1975) key to couplet 4 because of the bare mediotergite. Of the two alternatives it is more similar to M. geranias (LoEw) because of the coloration of the scutum. CHANDler (1994) distinguished two other species - M. veleka Bechev and M. guichardi Chandler - close to M. geranias. From these, the new species resembles $M$. guichardi in entirely yellow halteres, which have a black knob in the other two species. By characteristics of the genitalia the new species is a typical species of the genus, as outlined by Chandler (1994). Chandler (op. cit.) noted that Macrorrhyncha WINNERTZ is represented in the Mediterranean region by at least three additional undescribed species. The figures of male genitalia were sent to $\mathrm{Mr}$. CHANDLeR, who kindly informed me that they did not belong to one of these species.

\section{Neoplatyura nigricauda (Strobl, 1893)}

A close species to $N$. flava (MACQUART) distinguished by coloration and structure of male genitalia, which are figured by LANDrock (1927) and Hutson et al. (1980). Widely distributed in western and central Europe, and also in the Mediterranean (CHANDler 1994, BeCHEv 1997).

Material. Cyprus. 1 o , Troodos mts., river Kyros S of Pano Platres, 900-1100m, 1924 X 1992, P. Oosterbroek and F. M. Hartveld leg.

\section{Family Mycetophilidae}

Subfamily Gnoristinae

Boletina gripha DzIEDzIcKa, 1885

Widely distributed in Europe, recorded also from Middle Asia, Siberia and the Russian Far East (Zartzev 1994). In the Balkan Peninsula recorded from Bulgaria and BosniaHercegovina (BeCHev 1997).

Material. Greece. 1 ơ, Fokis, Oros Parnassos 15 km NW Arahova, 29 IV 1990, J. Lucas leg.

\section{Coelosia fusca BezzI, 1892}

Western Palaearctic species (SøL 1997). Occurs widely in the Mediterranean region (Chandler \& Ribeiro 1995). 
Material. Greece. 3 우, Attiki, Dafni, $10 \mathrm{~km} \mathrm{~W}$ Athens, Malaise trap in phrygana, 16 XII and 27 XII 1991, Th. Petanidou and G. Priebe leg.

\section{Subfamily Leiinae}

Docosia lastovkai CHANDLER, 1994

Fully described and figured by Chandler (1994). Found in Crete, Rumania, Bulgaria and Israel (CHANDLER op. cit.).

Material. Greece. $1 \sigma^{\star}$, Kos, Mt. Dikeos N of Zia, 400 m, 26 IV 1993, P. Oosterbroek and F. M. Hartveld leg.

\section{Docosia sp.}

The genus is well represented in the Mediterranean region (CHANDLER 1994) but females are partially undescribed and/or their terminalia are unfigured. It is impossible to determine a specimen to the species level.

Material. Greece. 1 \%, Rhodos, Lindos, 10 IV 1970, A. C. and W. N. Ellis leg.

\section{Ectrepesthoneura ledenikiensis $\mathrm{BECHEV}, 1988$}

(Fig. 4)

Described and figured by BECHEv (1988). Known so far only from the holotype from Bulgaria. The male IX tergite is figured again here (Fig. 4) to present the internal structure, which is somewhat similar to this of $E$. colyeri CHANDLER. The figure was sent to Dr. D. Bechev (Plovdiv) who kindly compared this with the holotype and confirmed the conspecificity.

Material. Greece. $1 \sigma^{\star}$, Poliana, rivulet in forest, $1000 \mathrm{~m}, 22022^{\prime} \mathrm{E} 36058^{\prime} \mathrm{N}, 18$ X 1991, H. Malicky leg. (determined by Dr. E. Plassmann as Ectrepesthoneura bucera Plassmann) [ZSM].

\section{Leia bimaculata (MEIGEN, 1804)}

Widely distributed in the Palaearctic (Zartzev 1994, Chandler 1994) including the Mediterranean region (Chandler 1994). According to Hutson et al. (1980) very variable in coloration. In studied material Greek specimens from Attiki and Rhodes are paler (scutum yellow with impressions of brown stripes and yellow pleura) than the Cyprus specimen (scutum brown with yellow shoulders and brown pleura). The female specimen from the Island Kos is wholly rusty with almost fused brown stripes on the scutum.

Material. Cyprus. 1 o, Lympia, 29 III 2000, A. Selin leg. [ASPC]. Greece. 1 o, Attiki, Dafni, $10 \mathrm{~km}$ W Athens, Malaise trap in phrygana, 12 XI 1992, Th. Petanidou and V. Lengiou leg.; 1 of 1 ㅇ, Rhodos, Lindos, 10 IV 1970, A. C. and W. N. Ellis leg.; 1 \%, Kos Mt. Dikeos N of Zia 400 m, 26 IV 1993, P. Oosterbroek and F. M. Hartveld leg. 


\section{Megophthalmidia samosica sp. nov.}

(Figs. 5-10)

Type material. Holotype: male, Greece, Samos, Manolates, 24 IV 1988, J. Lucas leg. Paratypes: 2 우 오, Greece, Samos, Manolates, 20 and 24 IV 1988, J. Lucas leg.

Description. Male. Length of wing $2.6 \mathrm{~mm}$.

Head black. Scape dull brown, pedicel rusty, lighter than the scape. Pedicel with one strong and several shorter bristles at apical margin. Flagellar segments dull brown, 1.5 times as wide as long. Palpus brown with apical segment yellowish. Proboscis dull brown with pale yellow apical half, about as long as height of head.

Thorax entirely brownish black. Scutum slightly shining. Pleural parts slightly lighter. Scutellum with three pairs of bristles at margin and with shorter bristles between. Laterotergite with 3-4 weak bristles posteriorly.

Legs yellow with bristles black. Mid and hind coxae darkened. Fore tibia with 3 dorsal setae near tip. Mid tibia with 5 a, 1 ad (at apical margin), $4 \mathrm{~d}$ and $4 \mathrm{p}$. Hind tibia with $14 \mathrm{a}$, about $25 \mathrm{~d}, 8 \mathrm{pd}$. Ratio of femur to tibia for fore, mid and hind legs: $1.08 ; 1.13$; 0.88. Ratio of tibia to first tarsomere for fore, mid and hind legs: $1.63 ; 1.70 ; 2.30$. Ratio of spur to first tarsomere for fore leg: 0.73 . Ratio of anterior and posterior spurs to first tarsomere for mid and hind legs: $0.5,0.65$ and $0.5,0.76$ respectively.

Wings hyaline. Radial veins and apical half of $\mathrm{r}-\mathrm{m}$ brown, with dense dark setae, other veins paler with setae sparse and weak. $R_{4}$, distal half of $r-m, t b, m$-stem, distal fourth of $M_{1}$ and distal fifth of $M_{2}$ asetose. $R_{1} 0.92$ times as long as $r-m$, which is 0.57 times as long as m-stem. Costa reaches halfway from $R_{5}$ to $M_{1}$. Sc distinctly ends in $\mathrm{R}$. Anterior fork begins at level of end of $R_{1}$. Posterior fork begins slightly before base of $m$-stem.

Abdomen entirely brownish black. Genitalia (Figs 7-10) with very complicated character. Gonocoxite with dorsal margins extended, forming bifurcate processes (Fig 7-10, a) and with additional slender moderately sclerotized lobes dorsally as well as ventrally (Figs $7-10, b, f)$. Gonostylus consists of four appendages: one large medially (Figs 7-10, e), two dorsally and one ventrally from this (Figs $7-10, \mathrm{c}, \mathrm{d}, \mathrm{g}$ ), the dorsal appendages bearing bristles while the ventral is moderately sclerotized.

Female. Length of wing $2.5-2.6 \mathrm{~mm}$. Coloration as in male. Setae on tibiae as in male. Ratio of femur to tibia for fore, mid and hind legs: $1.00 ; 1.11-1.17 ; 0.92-0.94$. Ratio of tibia to first tarsomere for fore, mid and hind legs: $1.80 ; 1.71-1.80 ; 2.09-2.20$. Ratio of spur to first tarsomere for fore leg: 0.84 . Ratio of anterior and posterior spurs to first tarsomere for mid and hind legs: $0.57-0.60,0.77-0.80$ and $0.48-0.54,0.79-0.85$ respectively. Wings hyaline. Costa reaches more than halfway from $R_{5}$ to $M_{1}$. Anterior fork begins at level of end of $R_{1}$. Posterior fork begins slightly before base of m-stem. $R_{1} 1.60$ times as long as $\mathrm{r}-\mathrm{m}$, which is 0.39 times as long as $\mathrm{m}$-stem. Abdomen entirely brownish black. Ovipositor as Figs 5-6.

Biology. Unknown.

Etymology. From the type locality in the Island of Samos: adjective.

Discussion. Until now only two European species of Megophthalmidia were known. $M$. decora (SANTOS ABREU), of which the systematics are discussed and terminalia figured by CHANDLER \& Ribeiro (1995), is described from female material only and considered to be endemic in 
the Canary Islands. $M$. crassicornis (CuRTis) is more widely distributed, recorded from Czech and Slovak Republics, Switzerland, Germany, France, Great Britain, Ireland, Netherlands, Poland and Sweden (Hackman et al. 1988, Košel et al. 1997, Chandler 1998, Kallweit \& Plassmann 1999). The male genitalia of $M$. crassicornis are figured by Hutson et al. (1980). The third European species - M. rufina (SCHNUSE) - referred in Palaearctic Catalogue (HACKMAN et al. 1988) was recently found to be a junior synonym of $M$. crassicomis by KaLLWEIT \& Plassmann (1999). According to Chandler \& Ribeiro (1995) there are at least four undescribed species found in Mediterranean material. After seeing figures of male genitalia Mr. Chandler kindly confirmed that the species described here is unknown to him, but two undescribed species from Cyprus and the mainland of Greece have genital structure indicating close relationship to $M$. samosica. Male genitalia of the new species are also somewhat similar to those of the only East-Palaearctic species $M$. takagii SasaKaWa found in Japan (Hokkaido) and the Russian Far East (SaSAKawa 1964, ZaItzev 1999).

\section{Subfamily Mycetophilinae}

\section{Brevicornu verralli (EDWARDS, 1925)}

Widely distributed in Europe with several records from the Mediterranean including Cyprus (Chandler 1994). According to Zartzev (1985) found also in South Korea. Association of the female is tentative, based only on same collecting data.

Material. Cyprus. $1 \sigma^{\star} 1$ ㅇ, Troodos mts., river S of Mesopotamos Monastery, 900$1100 \mathrm{~m}, 20$ X 1992, P. Oosterbroek and F. M. Hartveld leg.

\section{Exechia fulva SANTos ABreu, 1920}

A common species in the Mediterranean region (Chandler \& Ribeiro 1995). There are several unpublished records from mainland Greece as well as from its Islands (CHANDLER 1994). According to external characteristics - especially by smoke coloured spots ventrobasally on mid and hind femora, and by fore metatarsus subequal to its tibia - the female specimens could be associated with E. fulva in spite of not exactly the same collecting data. The female terminalia match those figured by Burghele-BALACEsCo (1966).

Material. Cyprus. 1 \& , Troodos mts., river S of Mesopotamos Monastry, 900-1100m, 20 X 1992, P. Oosterbroek and F. M. Hartveld leg.; 1 ㅇ, Troodos mts., river Kyros S of Pano Platres, 900-1100m, 19-24 X 1992, P. Oosterbroek and F. M. Hartveld leg. Greece. 1 o 1 \%, Attiki, Dafni, $10 \mathrm{~km}$ W Athens, Malaise trap in phrygana, 9 XII 1991 and 9 I 1992, Th. Petanidou and G. Priebe leg.

\section{Rymosia beaucournui MaTILE, 1963}

A Mediterranean species but recorded also from Switzerland (Chandler 1994, 1998). According to ChandleR (1994) there are unpublished records from mainland Greece. Belonging to a monophyletic group with $R$. tolleti Burghele-Balacesco, $R$. cottii Tollet, $R$. fasciata (Meigen) and $R$. britteni Edwards (Burghele-Balacesco 1965).

Material. Greece. $1 \sigma^{*}$, Attiki, Dafni, $10 \mathrm{~km}$ W Athens, Malaise trap in phrygana, 13 II 1992, Th. Petanidou and G. Priebe leg. 


\section{Rymosia sp.}

The females of Rymosia WINNERTz species are previously associated with males mostly because of the same collecting data. There are no published keys and figures of female terminalia for several species are lacking. According to terminalia three species are clearly distinguished in studied material. Nevertheless, the association with males is not sufficiently supported.

Material. sp1. Cyprus. 1 ㅇ, Troodos mts., river $S$ of Mesopotamos Monastery, 900$1100 \mathrm{~m}, 20$ X 1992, P. Oosterbroek and F. M. Hartveld leg. Greece. 2 \& , Attiki, Dafni, $10 \mathrm{~km} \mathrm{~W}$ Athens, Malaise trap in phrygana, 2 XII 1991 and 71 1992, Th. Petanidou and G. Priebe leg.; sp2. Cyprus. 1 o , Troodos mts., river Kyros S of Pano Platres, 9001100m, 19-24 X 1992, P. Oosterbroek and F. M. Hartveld leg.; sp3. Greece. 1 i, Attiki, Dafni, $10 \mathrm{~km}$ W Athens, Malaise trap in phrygana, 25 XI 1991, Th. Petanidou and G. Priebe leg.

\section{Tarnania dziedzickii (EDWARDs, 1941)}

Widespread in Europe (Hackman et al. 1988). According to Chandler (1994) there are unpublished records from Greek Islands.

Material. Cyprus. 1 \%, Troodos mts., river S of Mesopotamos Monastery, 900-1100m, 20 X 1992, P. Oosterbroek and F. M. Hartveld leg.

\section{Mycetophila perpallida CHANDLeR, 1993}

According to Chandler (1993) it is a widespread species in Europe including the Mediterranean region. The differences from the sibling species $M$. fungorum (DE GeER) appear only in the male genital structure. The females referred herewith are associated by same collecting data only.

Material. Greece. $50^{\star} 3$ 우, Attiki, Dafni, $10 \mathrm{~km}$ W Athens, Malaise trap in phrygana, 25 XI 1991, 2 XII 1991, 9 XII 1991, 23 XII 1991, 20 I 1992, and 23 IV 1992, Th. Petanidou and G. Priebe leg.

\section{Zygomyia sp.}

The specimen belongs to the $Z$. humeralis (WIEDEMAN) group, where only male specimens are distinguishable and females have not been associated (CHANDLER 1991).

Material. Cyprus. 1 \& , Troodos mts., 2 km S Kakopetria 500-700 m, 15-24 X 1992, P. Oosterbroek and F. M. Hartveld leg.

\section{Subfamily Mycomyinae \\ Mycomya (Mycomyopsis) maura (WALKER, 1856)}

With a western Palaearctic distribution: Spain, Corsica, Britain, Ireland, Pyrenees (Väıs̈NEN 1984).

Material. Greece. 4 क 77 우, Lesbos, Mytilini, 23 III 1999, A. C. and W. N. EllisAdam. 


\section{Subfamily Sciophilinae}

\section{Azana flavobalterata STrobl, 1909}

A Mediterranean species: Spain, Crete, Cyprus, Bulgaria (Chandler 1994, Coher 1995, Chandler \& Blasco-Zumeta 2001). Discussed and figured by Chandler \& BlascoZumeta (2001). Described and figured, as A. bulgarense, also by CoHER (1995).

Material. Greece. $1 \sigma^{\star}$, Samos, Pithagorion, 20 IV 1988, J. Lucas leg.

\section{Allocotocera pulchella (CuRTIS, 1837)}

A widespread Holarctic species (ZarTzev 1994). A. pulchella is the only described species in this genus in the Palaearctic (SøLr et al. 2000), but a second darker coloured species exists in the Mediterranean region (CHANDLER pers. comm.)

Material. Greece. 1 \%, Samos, Pithagorion, 20 IV 1988, J. Lucas leg.

\section{Sciophila sp.}

Most Sciophila females cannot be associated with males.

Material. Greece. 1 ㅇ, Attiki, Dafni, $10 \mathrm{~km} \mathrm{~W}$ Athens, Malaise trap in phrygana, 10 II 1992, Th. Petanidou and G. Priebe leg.

\section{Acknowledgements}

I am much obliged to Dr. H. DE Jong and Dr. B. Brugge (Zoölogisch Museum Amsterdam, Nederland), Dr. W. SCHACHT (Zoologische Staatsammlung in München, Germany) and Mr. A. Selin (Tallinn, Estonia) for an opportunity to work with the collections and for the loan of material. My very special thanks are due to Dr. D. BeChev (Plovdiv, Bulgaria) for his kind advice and for comments on particular species. I am very grateful to Mr. P. Chandere (Melksham, United Kingdom) for his help and critical perusal of the manuscript. The study was financially supported by Estonian Science Foundation (Grant No 4990).

\section{References}

Bechev, D. 1988: Two New Species of Mycetophilidae from Bulgaria (Insecta, Diptera). - Reichenbachia Mus. Tierk. Dresden 25: 185-186.

BeCHEv, D. 1992: On the type specimens of Macrocera nigricoxa WINNERTz 1863 and Macrorrhyncha exempla (Plassmann 1978) (Insecta: Diptera: Mycetophiloidea). - Senckenbergiana biol., 72: 317-320.

BECHEv, D. 1997: Check-list of the fungus gnats (Diptera: Sciaroidea, excluding Sciaridae) of the Balkan peninsula. - Trav. Sci. Univ. Plovdiv, Animalia, 33: 9-22.

Burghele-Balacescu, A. 1965: Specii noi Mycetophilidae cavernicole din România. - Lucr. Inst. de speol. "Emil Rakovitâ", 4: 171-179.

Burghele-Balacescu, A. 1966: Les Mycetophilidae (Diptères) cavernicoles de la collection Biospeologica (IVe - VIII éries des "Grottes visitées"). - Inter. Journ. of Speleology, 2: 319-334.

Chandler, P. J. 1991: New species and additions to the British list of the fungus gnat genera Zygomyia WinNerTz and Sceptonia WinnerTz (Diptera, Mycetophilidae). - Br. J. Ent. Nat. Hist., 4: 143-155.

Chandere, P. J. 1993: The Holarctic species of the Mycetophila fungorum (DE GeER) group (Diptera: Mycetophilidae). - Br. J. Ent. Nat. Hist., 6: 5-11.

Chandler, P. J. 1994: Fungus gnats of Israel (Diptera: Sciaroidea, excluding Sciaridae). - Israel Journal of Entomology, 28: 1-100.

Chandler, P. J. 1998: 20. Mycetophilidae. - In: Merz, B., Bächli, G., Haenni, J.-P. \& Gonseth, Y. (eds.). Fauna Helvetica 1. Diptera - Checklist. CSCF und Schweizerische Entomologische Gesellschaft: $113-125$. 
Chandler, P. J. 2000: Fungus gnats (Diptera: Keroplatidae and Mycetophilidae) from the Arabian peninsula. - Fauna of Arabia, 18: 273-284.

Chandler P. J. \& Ribeiro, E. 1995: The Sciaroidea (Diptera) (excluding Sciaridae) of the Atlantic Islands (Canary Islands, Madeira and the Azores). - Boletim do Museu Municipal do Funchal (Historia Natural), Suplemento No. 3: 1-170.

Chandier, P. J. \& GatT, P. 2000: Fungus gnats (Diptera: Bolitophilidae, Keroplatidae and Mycetophilidae) from the Maltese islands. - Studia Dipterologica, 7: 69-81.

Chandler, P. J. \& Blasco-Zumeta, J. 2001: The fungus gnat (Diptera, Bolitophilidae, Keroplatidae and Mycetophilidae) of the Monegros region (Zaragoza, Spain) and five other new European species of Pyratula Edwards and Sciophila Mergen. - Zapateri Revta, aragon. ent., 9: 1-24.

Coner, E. I. 1995: Contribution to a revision of the genus Azana WALKER, 1856 (Insecta: Diptera: Mycetophilidae: Sciophilinae), - Reichenbachia Staatliches Museum für Tierkunde Dresden 31: 83-91.

Hackman, W.; Laštovka, P.; Matile, L. \& Väisänen, R. 1988: Family Mycetophilidae (Fungivoridae). - In: Soós, A \& PApp, L. (eds.). Catalogue of Palaearctic Diptera. Volume 3. Ceratopogonidae-Mycetophilidae, Budapest: 220-327.

Hutson, A. M.; ACKLAnd, D. M. \& Kidd, L. N. 1980: Mycetophilidae (Bolitophilinae, Ditomyiinae, Diadocidiinae, Keroplatinae, Sciophilinae and Manotinae) Diptera, Nematocera. - Handb. Ident. Brit. Insects. London 9, 3:111 pp.

Kallweit, U. \& Plassmann, E. 1999: Mycetophilidae. - In: Schumann, H., Bährmann R. \& Stark, A. (eds.). Checkliste der Dipteren Deutschlands. - Studia Dipterologica Supplement, Halle (Saale) 2: 61-69.

Košel, V.; Chandler, P. J. \& Martinovský, J. 1997: Mycetophilidae. - In: Chvala, M. (ed.). Check List of Diptera (Insecta) of the Czech and Slovak Republics. 130 pp. Karolinum - Charles University Press, Praha: 19-23.

Krivosheina, N. P. \& Mamaey, B. M. 1988: Family Macroceridae. - In: Soós, A. \& Papp, L. (eds.). Catalogue of Palaearctic Diptera. Vol. 3. Ceratopogonidae - Mycetophilidae. Budapest: 212-217.

LANDrock, K. 1927: Fungivoridae (Mycetophilidae). - In: Die Fliegen der Paläarktischen Region (LindNER, E., ed.) 8: 1-196.

LOEW, H. 1871: Beschreibungen europäischer Dipteren. Systematische Beschreibung der bekannten europäischen zweiflügeligen Insekten. Von Johann Wilherm Mergen. Halle 2: VIII+1-319.

Martinovskx́, J. 2001: New records on little-known western Palaearctic Macrocera Meigen, with a description of $M$. jonica sp. n. from Greece (Diptera: Keroplatidae). - Acta Univ. Carol. Biol. 45: 109-114.

Matile, L. 1975: Revision des Asindulum et des Macrorrhyncha de la region palearctique (Diptera, Mycetophilidae). - Annls. Soc. ent. Fr. (n. s.) 11: 491-515.

Matrle, L. 1977: Revision des Keroplatinae du genere Antlemon (Diptera, Mycetophilidae). - Annls. Soc. Ent. Fr. (n. s.) 13: 639-649.

Matile, L. 1986: Lidentite du "Ver de la Tipule de l'agaric" de Reaumur, et notes taxonomiques sur les Keroplatus Palearctiques (Diptera, Mycetophiloidea, Keroplatidae). - Annls. Soc. Ent. Fr. (n. s.) 22: 353-367.

ØKLAND, B. 1994: Diversity patterns of two insect groups within spruce forests of southern Norway. Doctor Scientiarium thesis 21 Ls: $129 \mathrm{pp}$.

SASAKAWA, M. 1964: Japanese Mycetophilidae V. Descriptions of three new species. - Akitu, 12: 1-4.

SøLI, G. E. E. 1997: The systematics and phylogeny of Coelosia WinnerTz, 1863 (Diptera, Mycetophilidae). - Ent. Scand. Suppl. 50: 57-139.

Søli, G. E. E.; Vockeroth, R. J. \& Matile. L. 2000: A. 4. Families of Sciaroidea. - In: Papp, L. \& Darvas, B. (eds.). Contribution to a Manual of Palaearctic Diptera. Appendix. Budapest: 49-92.

VÄrSÄNEN, R. 1984: A monograph of the genus Mycomya Rondani in the Holarctic region (Diptera, Mycetophilidae). -- Acta Zool. Fennica 177: 1-346.

Yakovlev, E. B. 1994: Palaearctic Diptera associated with fungi and myxomycetes. Petrozavodsk: 127 pp. (in Russian, with English summary).

ZAITZEV, A. I. 1985: Holarctic species of fungus gnats of the genus Brevicornu, groups fissicauda and proximum (Diptera, Mycetophilidae). - Vestn. Zool., 5: 40-47. (in Russian).

ZarTzev, A. I. 1994: Fungus gnats of the fauna of Russia and adjacent regions. Part 1. Moscow: 288 pp. (in Russian).

ZarTzeV, A. I. 1999: Bolitophilidae. Diadocidiidae. Ditomyiidae. Keroplatidae. Mycetophilidae. - In: LEHR, P. A. (ed.). Key to insects of Russian Far East., Vladivostok: 134-239. (in Russian). 

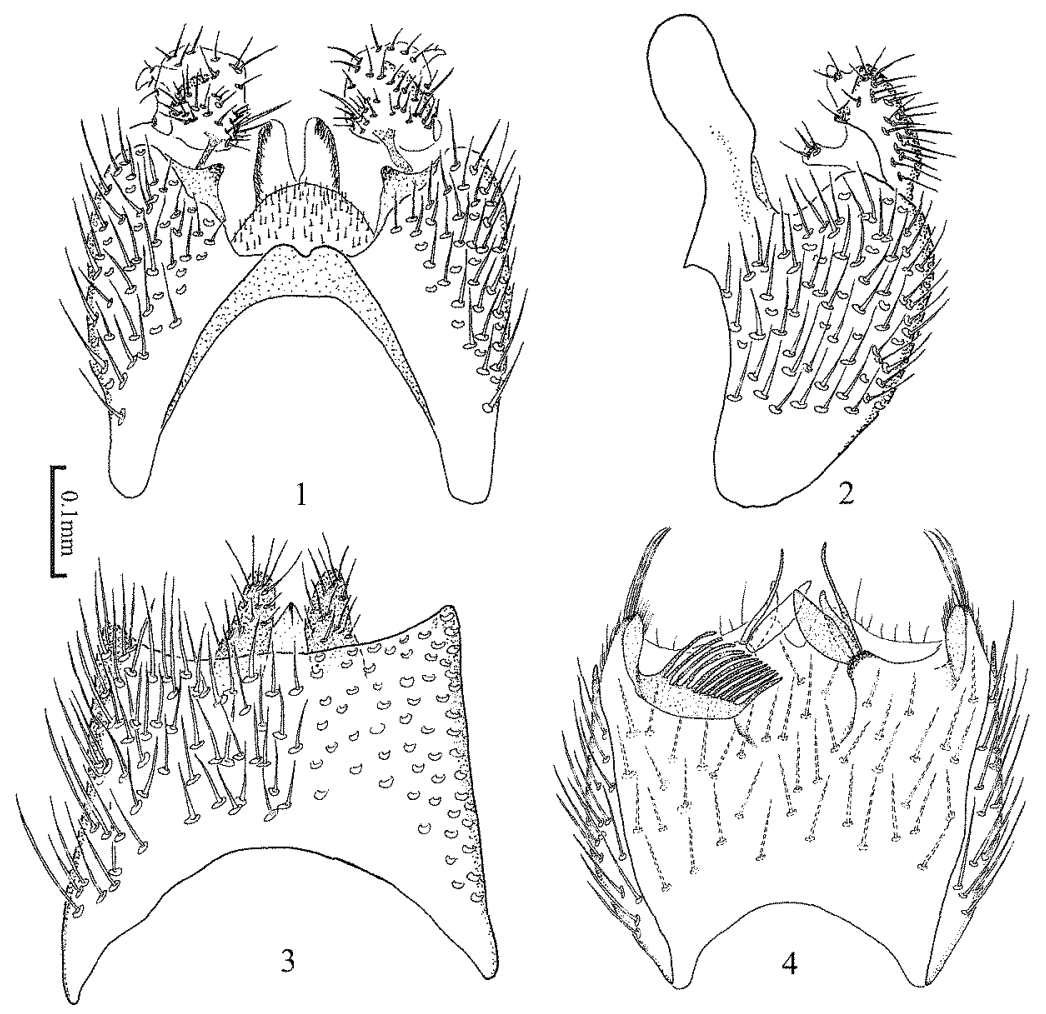

Figs. 1-4. Male genitalia of Macrorrhyncha atticae sp. nov. $(1,2,3)$ and Ectrepesthoneura ledenikiensis BECHEV, 1988 (4). 1, ventral view of gonocoxite and gonostyli; 2 , lateral view of gonocoxite and gonostylus; 3 , dorsal view of IX tergite and cerci; 4 , inner view of IX tergite.
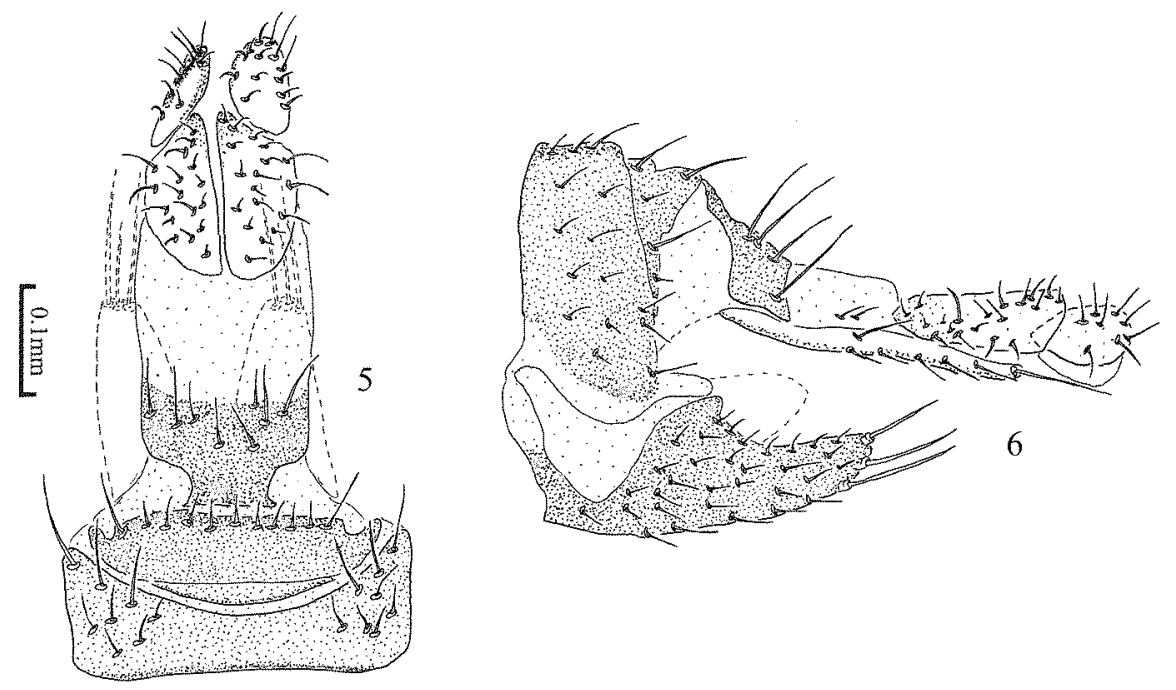

Figs. 5-6. Female terminalia of Megophthalmidia samosica sp. nov.; 5, dorsal view of ovipositor; 6, lateral view of ovipositor. 

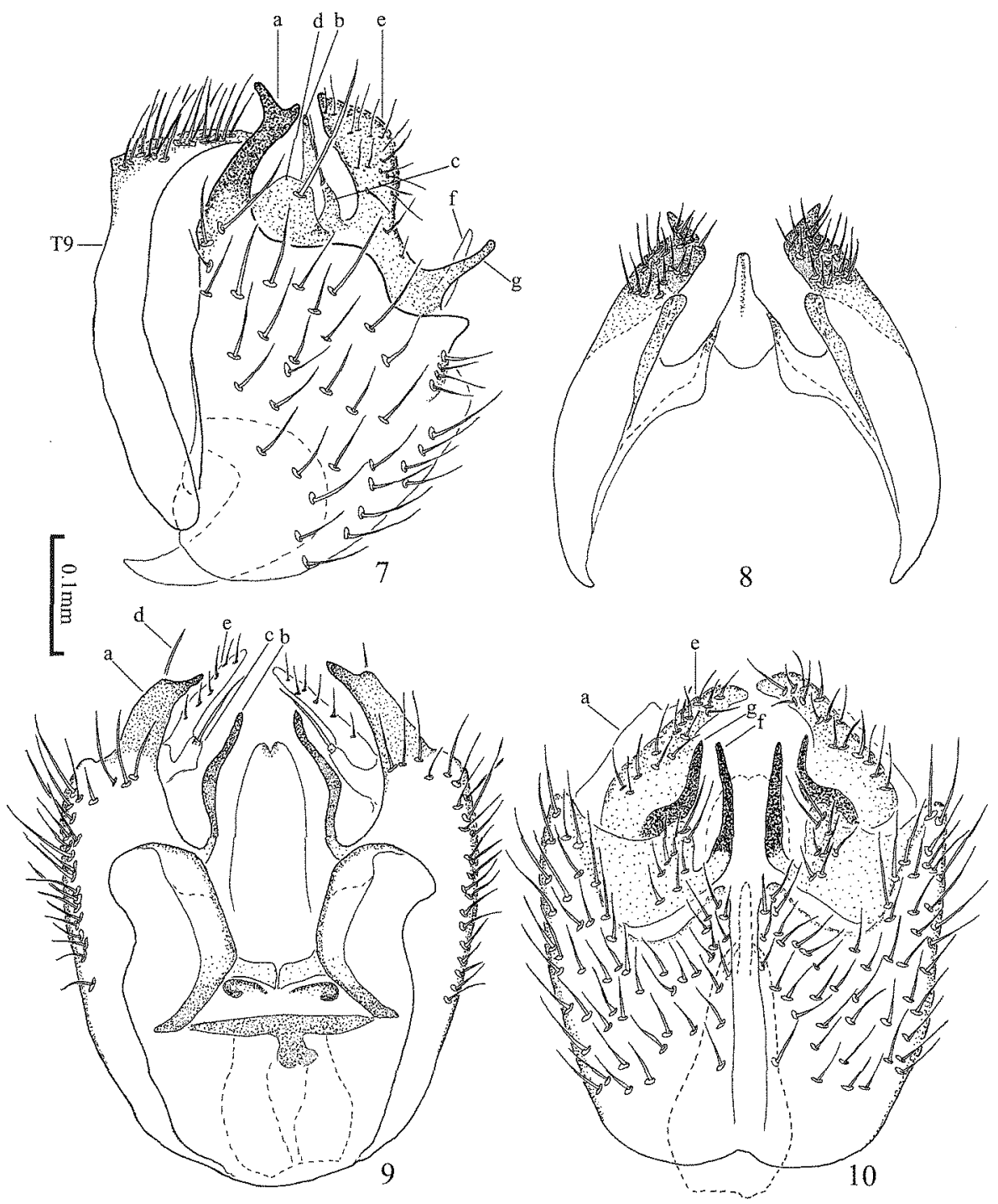

Figs. 7-10. Male genitalia of Megophthalmidia samosica sp. nov. (male). 7, lateral view of gonocoxite and gonostylus; 8 , dorsal view of IX tergite; 9 , dorsal view of gonocoxite and gonostyli; 10 , ventral view of gonocoxite and gonostyli. $\mathbf{a}$ - bifurcate dorsal process of gonocoxite; $\mathbf{b}$-dorsal process of gonocoxite; $\boldsymbol{c}, \mathbf{d}$ - bristle bearing dorsal appendages of gonostylus; $e$ - large medial appendage of gonostylus; $f$ - ventral process of gonocoxite; $\mathrm{g}$ - ventral appendage of gonostylus; T9 - IX tergite.

\section{Author's address:}

\section{Dr. Olavi Kurina}

Institute of Zoology and Botany, Estonian Agricultural University

Riia st 181, 510014 Tartu, Estonia

e-mail: olavi@zbi.ee 